\title{
Domestic and International Challenges for the Textile Industry in Shaoxing (Zhejiang)
}

Shi Lu

Translator. Will Thornely

\section{(2) OpenEdition}

\section{Journals}

\section{Electronic version}

URL: http://journals.openedition.org/chinaperspectives/6776

DOI: 10.4000/chinaperspectives.6776

ISSN: 1996-4617

\section{Publisher}

Centre d'étude français sur la Chine contemporaine

\section{Printed version}

Date of publication: 1 September 2015

Number of pages: 13-23

ISSN: 2070-3449

\section{Electronic reference}

Shi Lu, « Domestic and International Challenges for the Textile Industry in Shaoxing (Zhejiang)», China Perspectives [Online], 2015/3 | 2015, Online since 01 January 2017, connection on 28 October 2019 URL : http://journals.openedition.org/chinaperspectives/6776 ; DOI : 10.4000/chinaperspectives.6776 


\section{Domestic and International}

\section{Challenges for the Textile Industry} in Shaoxing (Zhejiang)

ABSTRACT: This article recounts the transformations that have taken place in the textile industry in Shaoxing, Zhejiang Province, over the course of the past 30 years. It reveals the importance of the local setup and the links that have built up between companies, markets, and the state and its departments. It also exposes the difficulties experienced by companies as they try to adapt to their changing environment, whether in terms of opportunities offered by the domestic or international markets, or new regulations.

KEYWORDS: textile industry, clusters, developmental state, governance, market.

\section{Introduction}

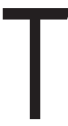
he developmental state concept was developed by Chalmers Johnson in the early 1980s to describe the role of the state in the economic successes enjoyed by Japan, which he considered to have been underestimated. (1) It was subsequently used to refer to the ability of economic bureaucracies to guide development in South Korea and Taiwan, channelling private investment towards growth sectors and allowing these economies to benefit from a comparative advantage in international competition. One of the distinctive traits attributed by Chalmers Johnson to developmental states was the absolute and unwavering priority given by government decision-makers to the aim of economic growth. Another was the alliance that formed between the political and economic elites in order to transform the industrial structure of the nation with a view to increasing its international competitiveness. The effectiveness of this particular form of state intervention in the economy was cast into doubt by the Asian financial crisis of the late 1990s, which gave rise to a neoliberal vision of government action that promoted a minimalist vision of such intervention. A decade later, the global economic crisis of 2008 gave the state a role of renewed importance in economic regulation. This brought the developmental state concept back to the fore, including in scientific debates. (2)

In the case of the People's Republic of China, Chalmers Johnson's concept has been illustrated by a number of publications. The analysis has focused in particular on collaboration between public decision-makers and business people at the local level, in townships and rural counties. For example, several authors have coined and used the concept of local state corporatism. (3) Since these publications, the national and economic context has evolved greatly, with transformations taking place in the systems organising production and the forms of governance. China's accession to the World Trade Organisation (WTO) at the start of the twenty-first century brought further changes to the field of play. Competition in the Chinese and international markets increased, the cost of labour rose, and new environmental requirements were imposed. This contribution looks back over the transformations and the ways in which companies have adapted to these changes in the case of the textile industry in Zhejiang Province and, more particularly, in the city of Shaoxing.

In 2013, 15\% of companies in Zhejiang Province were operating in the textile and clothing industries, making it one of China's main centres for manufacturing textile products at that time. (4) The city of Shaoxing, a former rural district with a long tradition of small-scale silk manufacturing, is the pillar of the textile industry in the province. The industry only emerged at the start of the 1980s but has experienced continuous growth ever since, its development characterised by the concentration of small family concerns in rural areas, which can be seen throughout Zhejiang. As well as being part of a manufacturing region, Shaoxing is also a market city. Today, China Textile City (Zhongguo qingfang cheng 中国轻纺城) in Shaoxing and the raw materials market in the town of Qianqing are among the largest textile markets in the whole of Asia (see Map 1). After some 20 years of strong growth, the twenty-first century has seen Shaoxing's textile industry adopt

With warm thanks to Gilles Guiheux for his advice and help.

1. Chalmers Johnson, Miti and the Japanese Miracle: The Growth of Industrial Policy: 1925-1975, Stanford, Stanford University Press, 1982

2. See Pauline Debanes and Sébastien Lechevalier, "La résurgence du concept d'État développeur: quelle réalité empirique pour quel renouveau théorique ?," (The resurgence of the concept of developmental state: Which empirical reality for which theoretical renewal?), Critique internationale, No. 63, April-June 2014, pp. 9-18.

3. Jean C. Oi, "The Role of the Local State in China's Transitional Economy," The China Quarterly, No. 144, December 1995, pp. 1132-1149; Jean Chun Oi, Rural China Takes Off: Institutional Foundations of Economic Reform, Berkeley and Los Angeles, University of California Press, 1999; Jonathan Unger and Anita Chan, "Inheritors of the Boom: Private Enterprise and the Role of Local Government in a Rural South China Township," The China Journal, No. 42, 1999, pp. 45-74.

4. Zhejiangsheng tongjiju (Statistics bureau of Zhejiang Province), Zhejiangsheng disanci jingji pucha zhuyao shuju gongbao - No. 2 (Communiqué on the main statistical data of the economy of Zhejiang - No. 2), 4 February 2015, p. 2, available at www.zj.stats.gov.cn/tjgb/jjpcgb/201502/ t20150204_152720.html (accessed on 2 June 2015). 


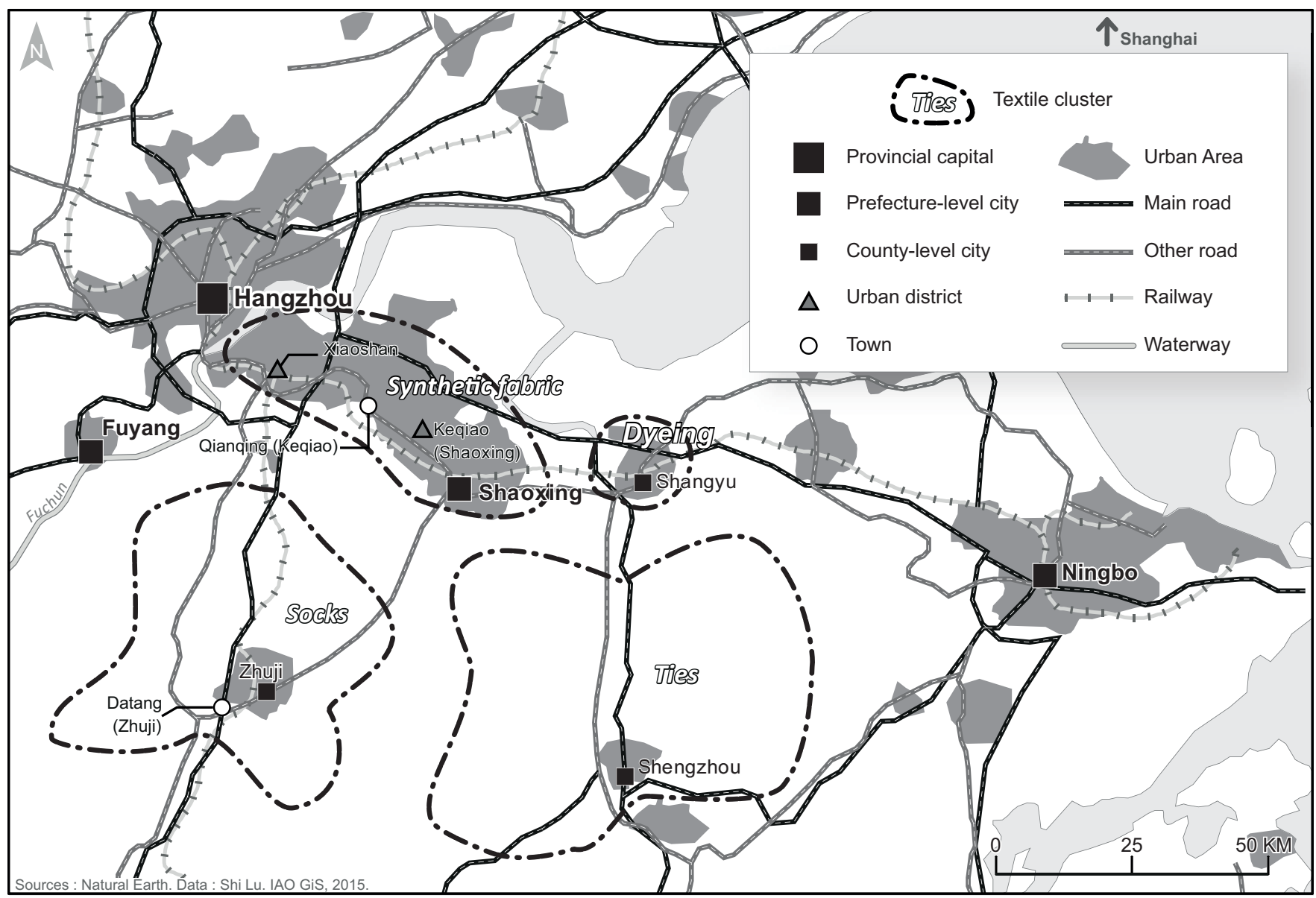

new strategies in order to remain competitive on a global scale, including a move towards more upscale products, greater consideration for the environment, an increase in innovation, and a more international outlook.

How has it been possible for industrial centres with such a strong focus on textiles to develop in this area over a 30-year period, given its lack of a strong industrial tradition? What economic, political, and social approaches have made these changes possible? The companies should not be viewed as independent or isolated production units, because they are not acting alone and maintain many links with political actors based on relationships of both collaboration and dependence. It therefore seems that understanding how these companies adapt to changes in the local setup requires bringing to light the relationships between the companies and local political power and forms of governance. Based on observations on the ground in the former district of Shaoxing and in the sub-prefecture-level city of Zhuji, we focus in the first part of this article on the transformations in the ways in which production was organised in the 1980s and 1990s, the links between industrial activities and trading activities, and the evolution in the role of the state locally in terms of economic management and the relations between economic trends and public action. The focus of the second part of the article is on the new challenges faced by the textile industry of Zhejiang and Shaoxing in the twenty-first century, and the role played by local government in the new economic climate.

The data forming the basis of this study were gathered between 2006 and 2011. (5) Interviews were carried out with private business people and public actors in order to learn more about the development of rural industry, the ways in which production is organised, and the forms of governance in companies. Twelve interviews were conducted in July 2007 with business people from the textile industry (see Table 1 for the summary of companies in question), some producing finished articles (ready-to-wear clothing, curtains), others manufacturing fabrics, and still others producing machines. An interview carried out in 2011 with the mayor of Shaoxing municipality helped shed further light on recent changes, and our analysis also makes use of macroeconomic data and works of Chinese researchers.

\section{Shaoxing, a manufacturing and market city (1980s and 1990s)}

\section{Textiles: A key industry for Zhejiang Province}

China is currently the world's biggest producer of textiles and the number one exporter of clothing. The country's entry into the WTO at the end of 2001 gave the textile sector a boost, and between 2003 and 2008, textile production grew sharply in the country, rising by an average of $18.38 \%$ annually, with a peak of $26 \%$ in 2004 and 2005. (6)

5. This project was carried out as part of a joint project between the Institut d'Asie Orientale (Institute of East Asian Studies) of ENS in Lyon and the Centre Max Weber (CNRS-Université Lyon 2). Zhejiang University College of Economics provided assistance in organising some interviews.

6. Zhejiangsheng Shangwuting (Zhejiang Bureau of Commercial Affairs), "Shinianlai woguo fangzhiye yunxing qingkuang" (Situation of the textile industry over the past ten years), available at http://zhejiang.mofcom.gov.cn/article/sjgongzuody/201108/20110807701957.shtml (accessed on 22 February 2015) 


\section{Table 1 - Summary table of companies visited in July 2007}

\begin{tabular}{|c|c|c|c|c|c|c|c|}
\hline 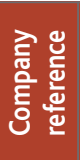 & $\begin{array}{l}\text { Age, gender, } \\
\text { and information about the } \\
\text { company director }\end{array}$ & $\begin{array}{l}\text { Past and } \\
\text { present legal } \\
\text { status of } \\
\text { the company }\end{array}$ & $\begin{array}{l}\text { Products } \\
\text { and } \\
\text { sectors of } \\
\text { activity }\end{array}$ & $\begin{array}{l}\text { Subcontracting / } \\
\text { own brand }\end{array}$ & $\begin{array}{l}\text { Number of } \\
\text { employees }\end{array}$ & Markets & $\begin{array}{l}\text { Location } \\
\text { of compa- } \\
\text { nies }\end{array}$ \\
\hline 1 & $\begin{array}{l}40 \text { years old, male. } \\
\text { Salesman in an import/export company, } \\
\text { started working for a collective factory } \\
\text { in 1994. Director } \\
\text { in 1998. }\end{array}$ & $\begin{array}{c}\text { TVE }^{*} \\
\text { until } 1994, \\
\text { then limited liability } \\
\text { company }\end{array}$ & Curtains & $\begin{array}{l}\text { Subcontracting } \\
\text { and own brand } \\
\text { in 1994, the first } \\
\text { in Shaoxing }\end{array}$ & 100 & $\begin{array}{l}\text { Before } 2000: 100 \% \text { in } \\
\text { the Chinese market / } \\
\text { Since } 2000: \\
80 \% \text { exports; } 20 \% \text { in the } \\
\text { Chinese market }\end{array}$ & $\begin{array}{l}\text { Qianqing } \\
\text { township } \\
\text { (Keqiao) }\end{array}$ \\
\hline 2 & $\begin{array}{l}46 \text { years old, male. } \\
\text { Salesman in an import/export company, } \\
\text { factory director in } 1994 .\end{array}$ & $\begin{array}{l}\text { TVE until 1994, then } \\
\text { family-run limited } \\
\text { liability company ** }\end{array}$ & $\begin{array}{l}\text { Embroidery, } \\
\text { fabrics }\end{array}$ & Subcontracting & 700 & $100 \%$ exports & $\begin{array}{l}\text { Qianqing } \\
\text { township } \\
\text { (Keqiao) }\end{array}$ \\
\hline 3 & $\begin{array}{l}59 \text { years old, female. } \\
\text { Barefoot doctor, director of a rural } \\
\text { collective sock factory in 1970, } \\
\text { township leader in 1984, private } \\
\text { company director in } 1999 .\end{array}$ & $\begin{array}{l}\text { TVE } \\
\text { until 1999, } \\
\text { then family-run } \\
\text { limited liability } \\
\text { company }\end{array}$ & $\begin{array}{l}\text { Ready-to-wear, } \\
\text { dyeing, property }\end{array}$ & $\begin{array}{l}\text { Subcontracting } \\
\text { and own brand }\end{array}$ & $\begin{array}{l}200 \text { (ready-to- } \\
\text { wear factory) }\end{array}$ & $\begin{array}{c}\text { Previously: } 90 \% \text { Chinese } \\
\text { market and } 10 \% \text { exports } \\
\text { / In 2007: } \\
50 \% \text { Chinese market } \\
\text { and } 50 \% \text { exports }\end{array}$ & Keqiao \\
\hline 4 & $\begin{array}{l}50 \text { years old, male. } \\
\text { Employee in a rural collective factory, } \\
\text { chief of town, company director. }\end{array}$ & $\begin{array}{l}\text { Joint venture from } \\
2000 \text { to } 2003, \text { then } \\
\text { limited liability } \\
\text { company }\end{array}$ & Fabrics & $\begin{array}{l}\text { Subcontracting } \\
\text { and own brand }\end{array}$ & 1,800 & $\begin{array}{c}70 \% \text { Chinese market, } \\
30 \% \text { exports }\end{array}$ & Keqiao \\
\hline 5 & $\begin{array}{l}45 \text { years old, male. } \\
\text { Worker in a rural company in 1984, then } \\
\text { technical manager, then private } \\
\text { company director in } 1993 .\end{array}$ & $\begin{array}{l}\text { TVE, then family-run } \\
\text { limited liability } \\
\text { company in } 1993\end{array}$ & $\begin{array}{l}\text { Synthetic } \\
\text { fabrics, cotton } \\
\text { and linen } \\
\text { fabrics, dyeing }\end{array}$ & Subcontracting & 700 & $100 \%$ exports & Keqiao \\
\hline 6 & $\begin{array}{c}35 \text { years old, male } \\
\text { Security manager in a dyeing company, } \\
\text { then director of a rural company from } \\
1997 .\end{array}$ & $\begin{array}{l}\text { TVE, then limited } \\
\text { liability company } \\
\text { in } 1997\end{array}$ & Dyeing & Subcontracting & 1,200 & $\begin{array}{l}\text { Chinese market } \\
\text { and exports }\end{array}$ & Keqiao \\
\hline 7 & $\begin{array}{l}55 \text { years old, female. } \\
\text { Created a sewing room in the form of a } \\
\text { TVE in 1989. Director of the privatised } \\
\text { company in } 1993 .\end{array}$ & $\begin{array}{l}\text { TVE, then family-run } \\
\text { limited liability } \\
\text { company in } 1997\end{array}$ & $\begin{array}{c}\text { Clothing: shirts, } \\
\text { trousers }\end{array}$ & $\begin{array}{l}\text { Subcontracting } \\
\text { and own brand }\end{array}$ & 600 & $\begin{array}{c}30 \% \text { Chinese market, } \\
70 \% \text { exports }\end{array}$ & Zhuji \\
\hline 8 & $\begin{array}{l}40 \text { years old, male. } \\
\text { Family workshop with four brothers and } \\
\text { sisters, then private limited liability } \\
\text { company, then incorporated into a } \\
\text { diversified industrial group. }\end{array}$ & $\begin{array}{l}\text { Family workshop, } \\
\text { then limited liability } \\
\text { company in an } \\
\text { industrial group listed } \\
\text { on the stock market }\end{array}$ & $\begin{array}{l}\text { Clothing: shirts; } \\
\text { property, } \\
\text { pharmaceutical } \\
\text { products }\end{array}$ & $\begin{array}{l}\text { Subcontracting } \\
\text { and own brand }\end{array}$ & 3,000 & $\begin{array}{c}70 \% \text { Chinese market, } \\
30 \% \text { exports }\end{array}$ & Zhuji \\
\hline 9 & $\begin{array}{l}48 \text { years old, male. } \\
\text { Family workshop, then technical } \\
\text { manager in a rural family company in } \\
\text { 1998, then director of the privatised } \\
\text { company in } 2002 .\end{array}$ & $\begin{array}{l}\text { TVE, then limited } \\
\text { liability company } \\
\text { from } 2002\end{array}$ & $\begin{array}{l}\text { Spare parts for } \\
\text { embroidery } \\
\text { machines }\end{array}$ & Subcontracting & 400 & $\begin{array}{l}\text { Before 2004: } 100 \% \\
\text { Chinese market / } \\
\text { After 2004: } \\
\text { 50\% Chinese market } \\
\text { and 50\% exports }\end{array}$ & Zhuji \\
\hline 10 & $\begin{array}{l}38 \text { years old, male. } \\
\text { Family workshop, rural company } \\
\text { director in 2002, then director of a } \\
\text { limited liability company in } 2004 .\end{array}$ & $\begin{array}{l}\text { TVE, then limited } \\
\text { liability company from } \\
2004\end{array}$ & $\begin{array}{l}\text { Embroidery } \\
\text { machines }\end{array}$ & Subcontracting & 150 & $\begin{array}{l}\text { Before } 2006: 70 \% \\
\text { Chinese market } \\
\text { In 2007: } 60 \% \text { exports }\end{array}$ & Zhuji \\
\hline 11 & $\begin{array}{l}46 \text { years old, male. Family sock } \\
\text { workshop in 1984, salesman for raw } \\
\text { materials for socks, director of a rural } \\
\text { company that he created in 1992; the } \\
\text { privatised company joined an industrial } \\
\text { group in } 1995 .\end{array}$ & $\begin{array}{c}\text { TVE, then limited } \\
\text { liability company from } \\
1995\end{array}$ & $\begin{array}{c}\text { Socks, property, } \\
\text { mining }\end{array}$ & $\begin{array}{l}\text { Subcontracting } \\
\text { and own brand }\end{array}$ & 3,000 & $\begin{array}{c}\text { Before 2007: } \\
\text { 30\% Chinese market, } \\
\text { 70\% exports / } \\
\text { In 2007: } 50 \% \text { Chinese } \\
\text { market and } \\
50 \% \text { exports }\end{array}$ & Zhuji \\
\hline 12 & $\begin{array}{l}43 \text { years old, male. } \\
\text { Family sock workshop in } 1987 \text {, rural } \\
\text { company director in } 1994 .\end{array}$ & $\begin{array}{l}\text { TVE, then limited } \\
\text { liability company }\end{array}$ & Socks & $\begin{array}{l}\text { Subcontracting } \\
\text { and own brand }\end{array}$ & 700 & $\begin{array}{c}70 \% \text { exports, } \\
30 \% \text { Chinese market }\end{array}$ & Zhuji \\
\hline
\end{tabular}

* Township and village entreprises or TVE (xiangzhen qiye). / ** All shares in these limited liability companies belong to the family. 
In Zhejiang Province, the textile sector accounted for an average of $12.22 \%$ of industrial production between 2002 and 2008 , although a slowdown occurred in 2005 (see Table 2). In 2010, textiles represented 17.68\% of exports from the province. Nationally, in 2010, production in Zhejiang represented $20 \%$ of China's textile production and $24.09 \%$ of exports, making Zhejiang the country's main textile-exporting province. ${ }^{(7)}$

\section{An industry anchored in the territories}

Located in the north of Zhejiang Province, Shaoxing was a city of $4,416,600$ inhabitants at the end of 2013,(8) and was divided into three urban districts (Yuecheng, Keqiao, and Shangyu), one rural county (Xinchang), and two sub-prefecture-level cities (Zhuji and Shengzhou). In 2012, Shaoxing had eight textile clusters with a turnover in excess of 20 billion yuan. (9) Many of the textile companies were recent and small in size. In 2001 , of the 12,423 textile companies in the city, $92 \%$ had fewer than 200 employees and $90 \%$ had been created after $1992 .{ }^{(10)}$ The majority of textile activities were spread over four localities, each having a specialisation: Keqiao for synthetic fibres and cotton fabrics; Shangyu for cotton fabrics and dyeing; Zhuji for sock and shirt manufacture; and Shengzhou for tie manufacturing (see Map 1). As mentioned in Table 1, of the 12 companies we visited in 2007, two were located in the township of Qianqing in Keqiao (companies 1 and 2), four in Keqiao, the former county of Shaoxing (companies 2 to 6), and six others were based in Zhuji (companies 7 to 12).

Initially focusing on production with a very low technical level but responding to a high level of domestic demand, (11) production was specialised spatially, as summarised by the expression "one product per village and one sector per township" (yixiang yipin, yizhen yiye 一乡一品, 一镇一业). This saw the emergence of industrial clusters. ${ }^{12)}$ In 2008, there were 38 specialised clusters in Shaoxing, bringing together more than 60,000 textile companies. ${ }^{(13)}$

The take-off of the textile industry in the former county of Shaoxing ${ }^{(14)}$ was not based on the local tradition of small-scale silk and cotton weaving, but on the manufacturing of synthetic fabrics. Indeed, the 1980s saw many constraints weigh heavy on the more established traditions, among them the insufficient production of silk thread and the existence of administrative quotas for cotton. In contrast to this, no restrictions were placed on synthetic fabrics, and consumers could buy articles of this kind without presenting a ration ticket. ${ }^{(15)}$ Initially, the industry was essentially centred on collective production workshops (shedui qiye 社队企业) created by working class towns in the 1960s in the context of an economy of scarcity. In the 1980s, these organisations were transformed into Township and Village Enterprises or TVEs (xiangzhen qiye 乡镇企业).

As in the district of Shaoxing, the choice of sock production in Zhuji was not linked to traditional local activities but to the fact that opportunities were identified in the market. The director of company 12 gave the following account:

I started working in a sock workshop in my village in Anhua, next to Zhuji. Along with five or six members of my family, I borrowed money from our relatives and friends to start sock production in 1987. At the time, nylon socks were selling very well. We received lots of orders, so we subcontracted a proportion, by which I mean that we provided our neighbours with machines and raw materials. That's how the sock sector started to develop in Anhua, a village next to
Datang. Some of our subcontractors later set up their own workshops. ${ }^{(16)}$

At the start of the 1980s, socks were in high demand on the Chinese market, and on the whole, production could not keep up with demand. A few peasants from the village of Datang in Zhuji obtained some old machines at a reasonable price from Haining, Yiwu, and Shanghai. ${ }^{(17)}$ After adapting them, they sold them in the village. This is how the sock weaving business started in Datang. Gradually, in 14 townships and several dozen villages in the area around Datang, approximately 10,000 small and medium-sized companies were set up in the 1980s and 1990s, producing socks. ${ }^{(18)}$ After a period of strong growth in the 1980s, the rural companies found their development was limited by their shortage of capital and technological weakness in a context of increased domestic and international competition. As a result, the companies and local government saw that they would need to be innovative.

\section{Early innovations}

Initiatives were thus taken in three fields: technology, marketing (the creation of own brands), and product design. In the second half of the 1990s, the district of Shaoxing encouraged the renewal of production equipment,

7. Zhejiangsheng kexue jishuting (Science and Technology Department of Zhejiang Province) Zhejiangsheng fangzhi gongye "shierwu" fazhan guihua (12th five-year plan of the Zhejiang textile industry), available at http://webcache.googleusercontent.com/search?q=cache:DV-xUrTwq80]: elearning.zjff.net/suite/resource/download.do\%3Fkey\%3D6431126\%26pointType\%3D1+\&cd=1 $\& h l=f r \& c t=c l n k \& g l=a u$ (accessed on 5 September 2014).

8. Shaoxingshi tongji diaocha xinxiwang (Website of the Statistics and investigation Bureau of Shaoxing), Shaoxingshi tongji nianjian - 2013 (Shaoxing statistical yearbook - 2013), 12 March 2015, available at www.sxstats.gov.cn/index.php? $m=$ content\& $c=$ index\&a=show\&catid $=42 \&$ id $=6659$ (accessed on 1 June 2015).

9. Zhejiang jingji he xinxihua weiyuanhui (Commission on economy and informatisation of Zhejiang Province), Zhejiangsheng gongye jingji gaikuang (Inventory of industry and the economy in Zhejiang), 2013, available at www.jhjxw.gov.cn/jxw/uploadfiles/\%E6\%B5\%99\%E6\%B1\%9F\% E7\%9C\%81\%E5\%B7\%A5\%E4\%B8\%9A\%E7\%BB\%8F\%E6\%B5\%8E\%E6\%A6\%82\%E5\%86\%B52 013\%EF\%BC\%88\%E4\%BF\%AE\%E8\%AE\%A2\%EF\%BC\%89.doc (accessed on 4 October 2014).

10. Zhang Haoliang, Zhejiang fangzhiye xianzhuang, tedian jiqi jingzhengli fenxi (Analysis of the situation, specificities, and competitiveness of the textile industry in Zhejiang), Guojia tongiju pucha zhongxin (General survey centre of the National bureau of statistics), p. 1, available at www.stats.gov.cn/ztjc/ztfx/decjbdwpc/200309/t20030909_38579.html (accessed on 12 October 2014).

11. Sheng Shihao, Zhejiang xianxiang - chanye jiqun yu quyu jingji fazhan (The Zhejiang phenomenon - industrial clusters and regional economic development), Beijing, Qinghua daxue chubanshe, 2004.

12. Major works that may have inspired the Chinese government's industrial policy: Michael E. Porter, The Competitive Advantage of Nations, New York, The Free Press, 1990; Wang Jici, Chuangxin de kongjian: qiu jin yu fazhan (Innovative spaces: Enterprise clusters and regional development), Beijing, Beijing daxue chubanshe, 2001; Giacomo Becattini, Industrial Districts: A New Approach to Industrial Change, Cheltenham, Edward Elgar Publishing, 2004.

13. Yu Binbin and Bao Xiyi, "Zhuanye shichang yu chanye jiqun hudong fazhan de jili yu duice yanjiu - yi Shaoxing fangzhi gongye weili" (Study on mechanism and strategies between specialised market and industry cluster - the Shaoxing textile industry as an example), Weilai yu fazhan, No. 9, 2010, pp. 25-30.

14. The county of Shaoxing was renamed Keqiao in October 2013, when it became an urban district incorporated into the city of Shaoxing.

15. Zhang Haoliang, Zhejiang fangzhiye xianzhuang, tedian jiqi jingzhengli fenxi (Analysis of the situation, specificities, and competitiveness in the textile industry in Zhejiang), op. cit.

16. Unless otherwise specified, the interviews were conducted in 2007

17. In Haining and Yiwu, the sock weaving business had been up and running since before the 1950 s. Some homes kept the machines they had used and then sold them to peasants from Zhuji in the 1980s. Similarly, factories in Shanghai sold their old machines when upgrading their equipment. See Zhu Huacheng, Zhejiang chanyequn - chanye wangluo, chengzhang guiji yu fazhan dongli (Industrial clusters of Zhejiang - networks, trajectories, and development), Hangzhou, Zhejiang daxue chubanshe, 2003, pp. 136-137.

18. Shi Jinchuan, Zhongguo minying jingji fazhan baogao (Report on the development of the private economy in China), Vol. 2, Beijing, Jingji kexue chubanshe, 2006. 
and between 1995 and 1998, the local government invested 1.2 billion yuan to help companies acquire more than 20,000 shuttleless weaving looms. This technology became widespread, and shuttleless looms, which had represented $0.24 \%$ of the weaving looms in 1990, accounted for more than $50 \%$ of them in 1998 and $72 \%$ in $2001 .{ }^{(19)}$ Shaoxing became the best equipped textile manufacturing centre in China. (20) In the sock-producing city of Zhuji, a number of companies imported computerised weaving machines from South Korea and Italy. (21)

Another innovation involved creating own brands in order to branch out from pure subcontracting work. The director of company 7, which manufactures clothing items in Zhuji, gave the following account:

Being a subcontractor limits the growth of the company. Initially, we were working for a Shanghai brand. For every shirt we produced, we were actually paying two yuan to the company in Shanghai. Later, when other factories also started to work for the same brand, the company in Shanghai increased the price to five yuan per shirt. We became too dependent on them. In 1994, we created our own brand and later obtained ISO 9000 certification. Our brand is now ranked as one of the best in China.

Finally, innovation also concerned the matter of design. While certain companies carried on operating as subcontractors or copied existing products, the larger concerns set up design studios in the provincial capital, Hangzhou, or signed training and research agreements with universities.

The innovations introduced in the 1990s helped Shaoxing become the flagship of the Chinese textile industry. The value of textile production in 1998 was four times higher than it had been in 1991, representing an average annual increase of $20 \%$. (22) Similarly, Zhuji became the largest sockproduction site. In 1998, approximately $50 \%$ of the socks sold on the Chinese market were produced in Zhuji. (23)

In a traditionally agricultural area, the industrial textile district of Shaoxing gradually structured itself into specialised production centres. This development trajectory went hand-in-hand with growth in trading activities, which made rural industrialisation possible in this area.

\section{Manufacturing production and marketing networks}

The Shaoxing region has a long history of commerce and a tradition of peddling traders. In the 1970s and 1980s, traders and pedlars started manufacturing products that had sold out in the collective shops, selling them in rural markets. Many specialised village markets began to operate in the 1980s in this way, including the raw materials market in the township of Qianqing, the markets specialising in socks and sock weaving machines in the township of Datang in Zhuji, and the textile market in the district of Shaoxing. The Shaoxing fabric market, which was founded in 1985 by the local authorities, grew to become China Textile City in the 1990s. Covering an area of more than three million square metres, it was home to some 24,000 traders in 2014, making it the largest textile product distribution centre in Asia. Approximately $25 \%$ of textile fabrics sold internationally pass through this market. ${ }^{(24)}$

Until the mid-1990s, textile products from Shaoxing and Zhuji mainly supplied the domestic market, and in particular the "markets of the three Norths" (sanbei shichang 三北市场): the Northeast, the North, and the Northwest. Starting in the second half of the decade, the provincial gov-

\section{Table 2 - Percentage of industrial production accounted for by the textile sector in Zhejiang Province, 2002-2008}

\begin{tabular}{|c|c|}
\hline Year & Percentage \\
\hline 2002 & $13.79 \%$ \\
\hline 2003 & $13.82 \%$ \\
\hline 2004 & $13.19 \%$ \\
\hline 2005 & $10.23 \%$ \\
\hline 2006 & $11.92 \%$ \\
\hline 2007 & $11.62 \%$ \\
\hline 2008 & $10.99 \%$ \\
\hline
\end{tabular}

Source: Wu Weiqiang, "Fangzhiye chukou dui Zhejiang GDP zengzhang de gongxian" (Contribution of textile exports to Zhejiang's GDP), Zhejiang tongji xinxi wang (website of the Statistical Bureau of Zhejiang Province), 23 December 2010, available at www.zj.stats.gov.cn/tjfx_1475/tjfx_sjfx/201012/t20101223_138264.html (accessed on 18 April 2015).

ernment set companies the priority objective of developing closer links between production and trade under the slogan: "Stimulating industry through trade and developing industry and trade hand-in-hand" (yi shangcugong, gongmao liandong 以商促工, 工贸联动). In the case of clothing company 8 , one of the largest in Zhejiang, the key to the company's success was the development of sales networks. In 2007, it had five sales agencies and 2,000 points of sale, allowing it to cover the whole of the domestic market.

At the end of the 1990s, the provincial government instigated a new strategy, encouraging companies to expand into the international markets. The main destinations were Asia, Africa, the Middle East, and America. The director of clothing company 3, based in Keqiao, related his experience with the foreign markets:

We are a small company of 200 employees producing clothing. In the past, we operated only in the Chinese market, but competition became too stiff, so we started to export. We have several factories. The dyeing factory exports to the Middle East, where we also sell clothes of our own brand. Our clothing factory performs subcontracting work for foreign brands. Our products are sold in the United States and Australia. Recently, with the United States adopting a quota policy, this has become more difficult. We are now looking to new markets in South Korea and Taiwan.

19. Sheng Shihao, Zhejiang xianxiang - chanye jiqun yu quyu jingji fazhan (The Zhejiang phenomenon - industrial clusters and regional economic development), op. cit., p. 180.

20. Qiu Mingjun and Ruan Mingfeng, "Shaoxing fangzhiye jiju xiaoyi fenxi" (Efficacy of the concentration of textile companies in Shaoxing), Jingjishi, No. 3, 2005, pp. 255-256.

21. Zhu Huacheng, Zhejiang chanyequn - chanye wangluo, chengzhang guiji yu fazhan dongli (Industrial clusters in Zhejiang - networks, trajectories and development), op. cit., p. 137.

22. Zhu Xiaobin and Lin Qing, "Zhongxiao qiye jiqun jingzheng youshi laiyuan de yanhua chayi - jiyu Zhejiang Shaoxing fangzhiye jiqun de anli yanjiu" (Differences in the evolution of competitiveness in small and medium enterprise clusters - the case of the textile cluster in Shaoxing), Guanli shijie, No. 10,2008 , pp. $75-86$.

23. Zhu Huacheng, Zhejiang chanyequn - chanye wangluo, chengzhang guiji yu fazhan dongli (Industrial clusters in Zhejiang - networks, trajectories, and development), op. cit., p. 125.

24. China Textile City (Zhongguo qingfang cheng) website, www.zgqf. gov.cn (accessed on 6 September 2014). 
The business people cited a number of factors when explaining their move towards internationalisation. First and foremost, they pointed to the fierce competition in the Chinese market, driven in part by counterfeiting. They also mentioned the lack of trust between companies and their Chinese clients, resulting from too many non-payments. Finally, government policy and the removal of export tax favoured the move towards exports. Previously, private companies were required to work with state-appointed import/export companies, or the Canton Fair, but from 2000 onward they were able to set up their own marketing facilities, which came in a variety of forms: an import/export department within the company, sales agencies, or branch offices abroad. Under these conditions, businessmen saw the move towards internationalisation as a move upmarket.

The swift development of industrial textile clusters in Shaoxing was therefore made possible by an improvement in production technologies and the construction of marketing networks, both on the domestic market and internationally. It was also facilitated by new forms of state intervention.

\section{The evolution of the role of the local state}

Reform led to the juxtaposition, superposition, and combining of old and new institutions. ${ }^{(25)}$ In the 1980s, economic reform was embodied in decentralisation (difang fenquan 地方分权) or a deconcentration of economic power. Local government played the main role in the local economy, while also answering to higher administrative levels. It was also responsible for the economic performances of the territory it administered, upon which its income and the careers of local leaders were dependent. ${ }^{(26)}$ Starting in 1994, a process of privatising collective companies was initiated. They shifted from having the status of collectives companies with a responsibility contract (chengbao hetong 承包合同) to that of cooperative shareholding companies (gufen hezuo qiye 股份合作企业). Over the course of this process, the local authorities transferred the companies to private individuals. Selling companies to their managers became common practice. ${ }^{(27)}$ This was the case with company 3 , for example:

I was a barefoot doctor in a rural collective factory, and was working at the same time in the administration of the factory. In 1984, I became factory director and then township leader. Starting in 1994, we changed our activity to producing socks. This was a time when the local government was encouraging lots of factory managers to assume control of collective rural companies. In 1999, our factory was transformed into a private company, and I am still the director. The other managers have become shareholders.

The vast majority of company directors interviewed progressed through these various stages (see Table 1). All were originally from Shaoxing or Zhuji, and they had all either been managers of rural collective workshops, appointed by the local authorities or local political leaders (township leaders), or sales or technical managers in companies. At the change in legal status of the companies, this responsibility was all but forced on them. The similar paths taken by the company directors suggests a high degree of continuity in terms of the men or women at the helm as institutional changes took effect in companies. This continuity proved an important factor in the success of the company, because it allowed networks of relationships to be built with the local authorities. The human relation dimension can be seen, to a certain extent, as the main resource of entrepreneurial activity. (28)
As the market economy took shape, the role of local government began to change. It now needed to fulfil a support role, providing a service to companies. The policy of the central government, including for large companies that remained in the hands of the state, was to separate ownership from management (guanban fenli 管办分离). While the local state now played a lesser role in local economic life, it could continue to play a direct role in the life of companies as a shareholder. This was the case, for example, at Textile City in Shaoxing. The market was semi-privatised in 1993, and from then on, management was officially passed to Zhejiang China Light \& Textile Industrial City Group, a private company. However, the local government continued to be its main shareholder. In 2008, the company was bought back by the government of Shaoxing, which became its owner once more.

What distinguishes the case of China from the other Asian countries that have experienced strong economic growth is that the local authorities at all administrative levels are closely connected to the bodies of the Chinese Communist Party (CCP); links between the state apparatus and companies therefore remain close. From the companies' perspective, although local government is no longer the main economic actor, it continues to act as a privileged collaborator whose support is essential if the company is to prosper. This support enables companies to obtain information and assistance more quickly, for example when acquiring land to accommodate company expansion, and in the form of support for innovation by research centres linked to the local government, or tax exemption. It is striking to observe the strong presence of political bodies in private companies, in particular those of a certain size. Starting in 1987, this phenomenon became widespread in the 1990s. The government in Shaoxing demanded the presence of a CCP cell in companies of more than 100 people that had a turnover in excess of 5 million yuan. Businessmen were not opposed to this policy. Company 6, for example, set up a Party cell, union representation, and a committee of the Communist Youth League. The director gave the following account:

These bodies are strongly recommended by the local authorities, and I do not have any problem with it. It is part of company culture. These bodies often organise parties, sports tournaments, and competitions. The aim, from my point of view, is to motivate the workers in their work so as to increase productivity.

We met the Party secretary of company 8 , one of the largest clothing companies in Zhejiang. He had been a senior civil servant in the municipality of Zhuji. After retiring, the company took him on to manage both the Party committee and the union. He was also a shareholder and sat on the board of directors of the company. The role of this Party secretary involved not only mediating between employees and management in order to ensure the smooth running of the company, but also acting as an interface between the company and local government. The Party representative became an intermediary, or indeed a protector of the company in its relations with the

25. Marie-Claire Bergère, Chine : Le nouveau capitalisme d'État (China: The New State Capitalism), Paris, Fayard, 2013, p. 80

26. Jean C. Oi, "The Role of the Local State in China's Transitional Economy," art. cit., pp. 1138-1139.

27. Jean-François Huchet, "The Hidden Aspect of Public Sector Reforms in China: State and collective SMEs in urban areas," China Perspectives, No. 32, 2000, pp. 37-48.

28. Gilles Guiheux, "The Revival of Family Capitalism: A Zhejiang entrepreneur," China Perspectives, No. 58,2005 , pp. 22-31. 
Table 3 - Exports of textiles and ready-to-wear from Zhejiang Province, 1998-2013

\begin{tabular}{|c|c|c|c|c|}
\hline Year & $\begin{array}{l}\text { Textile exports by value } \\
\text { (unit: US\$ } 1 \text { million) }\end{array}$ & $\begin{array}{c}\text { Textile exports } \\
\text { (year-on-year change) }\end{array}$ & $\begin{array}{l}\text { Read-to-wear exports by value } \\
\text { (unit: US\$ } 1 \text { million) }\end{array}$ & $\begin{array}{l}\text { Ready-to-wear exports } \\
\text { (year-on-year change) }\end{array}$ \\
\hline 1998 & 1,070 & & 3,030 & \\
\hline 1999 & 1,340 & $25.23 \%$ & 3,470 & $15 \%$ \\
\hline 2000 & 2,220 & $65.67 \%$ & 5,100 & $47 \%$ \\
\hline 2001 & 2,860 & $28.83 \%$ & 5,860 & $15 \%$ \\
\hline 2002 & 4,090 & $43.01 \%$ & 6,720 & $15 \%$ \\
\hline 2003 & 6,390 & $56.23 \%$ & 9,140 & $36 \%$ \\
\hline 2004 & 8,890 & $39.12 \%$ & 10,760 & $18 \%$ \\
\hline 2005 & 11,110 & $24.97 \%$ & 13,320 & $24 \%$ \\
\hline 2006 & 13,810 & $24.30 \%$ & 15,930 & $20 \%$ \\
\hline 2007 & 17,010 & $23.17 \%$ & 18,600 & $17 \%$ \\
\hline 2008 & 20,670 & $21.52 \%$ & 21,580 & $16 \%$ \\
\hline 2009 & 19,017 & $-8.00 \%$ & 20,739 & $-4 \%$ \\
\hline 2010 & 24,862 & $30.74 \%$ & 24,896 & $20 \%$ \\
\hline 2011 & 31,108 & $25.12 \%$ & 29,138 & $17 \%$ \\
\hline 2012 & 31,264 & $0.50 \%$ & 28,544 & $-2 \%$ \\
\hline 2013 & 35,368 & $13.13 \%$ & 31,883 & $12 \%$ \\
\hline
\end{tabular}

Source: 1998-2008: Bao Xiyi, Jinrong weiji beijingxia Zhejiang fangzhi gongye jingzhengli tisheng yanjiu (Study on the move upmarket of the textile industry in Zhejiang in the context of the financial crisis), Master's dissertation, Zhejiang Normal University, 2011, p. 31; 2009-2013: Zhejiangsheng tongjiju (Zhejiang Statistical Bureau), Zhejiang tongji nianjian 2014 (Zhejiang statistical yearbook, 2014), Beijing, Zhongguo tongji chubanshe, 2014, p. 413.

local state. This close-knit relationship with local political power ensured the success of private business people. Several of the company directors we spoke to were delegates to their local People's Assembly, members of the board of directors of sector associations (hangye xiehui 行业协会), or had obtained the title of "model entrepreneurs" (mofan qiyejia 模范企业家). Becoming a member of various political bodies allowed private business people to enjoy the trust of local political power, and thus ensure the success of the company.

While the 1980s and 1990s saw the textile industry flourish in Shaoxing, this rapid expansion appeared to reach a peak in the early 2000s. The new economic climate, the modernisation of the textile industry, and globalisation were all factors of change that required companies and political leaders to turn in new directions.

\section{The textile industry's new challenges since 2000}

\section{Opportunities and difficulties of internationalisation}

China's entry into the WTO in December 2001 helped it conquer international markets. On its entry, China became party to the Agreement on Textiles and Clothing and its accompanying rights and obligations. After enjoying a sharp rise in its textile and ready-to-wear exports, China met with hostile reactions from Western countries. In the early 2000s, exports of both textile articles and ready-to-wear items rose sharply. They then slowed until they reached negative figures in 2009, after which they experienced a recovery and renewed continual growth, but at a much slower rate than a decade earlier (see Table 3). This continual slowdown in the second half of the 2000s can be explained by the global financial crisis on the one hand, and by the revaluation of the yuan in 2005 on the other.

As with all other members of the WTO, the quotas imposed on textiles ended on 31 December 2004, but a safeguard mechanism remained in place until the end of 2008 to allow WTO member states to take measures to slow imports in case of market disruption. The United States, the European Union, and some ten other countries took anti-dumping measures. Moreover, the European Union's introduction of new standards in 2007 forced Chinese companies to improve the quality of their products.

Finally, in addition to new international regulations and customs barriers, the revaluation of the yuan and the reduction and subsequent removal of the export tax exemption applied by China between 2003 and 2007 all constituted additional constraints. Almost all of the companies we visited had moved into exports during the 1990 s, with $50 \%$ and up to $80 \%$ of production being sold abroad; they then gradually turned back towards the Chinese market. In 2003, 66\% of Chinese textile products were sold on the domestic market, this percentage rising to $75 \%$ in 2007. ${ }^{(29)}$ However, the difficulties encountered by companies were due not only to the conditions of access to international markets, but also to increasing costs in factors of production.

29. Nian Meng, "Zhongguo fangzhiye de xianzhuang jiqi fenxi" (Inventory and analysis of the textile industry in China), Shangye jingji, No. 1, 2009, pp. 25-26. 
Table 4 - Textile clusters in Shaoxing in $\mathbf{2 0 1 0}$

\begin{tabular}{|c|c|c|c|c|}
\hline Sector & $\begin{array}{c}\text { Number of companies } \\
\text { (with a turnover greater } \\
\text { than 5 million yuan) }\end{array}$ & Number of employees & $\begin{array}{c}\text { Sales turnover } \\
(100 \text { million yuan) }\end{array}$ & Location \\
\hline PTA * & 1 & 846 & 159.58 & $\begin{array}{c}\text { Binhai industrial area } \\
\text { (Maan township) }\end{array}$ \\
\hline Synthetic fibre & 63 & 18,135 & 424.37 & $\begin{array}{c}\text { Binhai industrial area (Maan township), } \\
\text { Qianqing township }\end{array}$ \\
\hline Dyeing & 197 & 80,022 & 393.68 & $\begin{array}{c}\text { Binhai industrial area (Maan township), } \\
\text { Qianqing township }\end{array}$ \\
\hline Weaving & 699 & 87,676 & 653.71 & $\begin{array}{c}\text { Qianqing, Lizhu, Lanting, and Yangxun townships } \\
\text { Binhai industrial area }\end{array}$ \\
\hline Clothing & 95 & 14,221 & 46.99 & Keqiao development area, \\
Qianqing and Anchang townships
\end{tabular}

Source: Government of the Shaoxing County, Shaoxingxian fangzhi chanye di shierwu fazhan guihua (12th five-year plan of the Shaoxing textile industry), September 2011, available at www.kqqqy.gov.cn/index.php?act=down\&id=248 (accessed on 10 May 2015). * Pure Terephthalic Acid is used in the production of certain textiles.

\section{Access to factors of production (land, raw materials, and labour)}

Given the large-scale expansion of industrial clusters in the 1990s, Zhejiang was no longer able to provide new land for growing companies. The quota policy concerning land acquisition implemented at the end of the 1990s cut off access to land to polluting companies and those operating at a low technological level. This left such companies with two alternatives: transferring their production out of the province, or closing their doors altogether. Zhejiang is also a province that lacks raw materials. Since it only produces a small amount of cotton, it relies mainly on purchases from other Chinese provinces or foreign imports, in particular from the United States and India. The sustained increase in the price of cotton during the 2000s, in particular between 2008 and the second half of 2010, when the price rose by $150 \%$, left a number of companies struggling. ${ }^{(30)}$

Companies also found themselves facing problems with the rapid turnover of labour and the lack of technical skills among migrant workers. The director of company 11 described the conditions of his employees and complained about public policies as follows:

Lots of companies try to improve the living conditions of their workers in order to encourage them to stay. $80 \%$ of the workers in our company are migrants. They are housed in air-conditioned dormitories and earn, on average, 1,600 yuan per month. These migrants do not know how to do anything, and need to be taught everything. The biggest problem is their mobility: often they leave with no warning. The only way to keep them is to increase their salary. Government policy gives migrant workers a lot more protection than employers.

Textile companies are also being forced to face up to ever-increasing labour costs. The average salary of workers is continually rising, especially since the new Labour Contract Law became effective on 1 January 2008 Wages in the textile sector increased by $10 \%$ in 2010 in China as a whole and by $20 \%$ in the Yangtze Delta area, and Shaoxing is the city with the highest salaries in the province for workers in this sector. ${ }^{(31)}$ The Chinese textile industry today faces stiff competition from the countries of South and Southeast Asia, with recent years seeing textile production shift towards Vietnam, India, and Pakistan.

Producing bottom-of-the-range products, the textile companies of Zhejiang are still, for the most part, small-scale subcontractors; they lack a competitive edge when exposed to international competition. In Zhejiang, in $2000,45 \%$ of fabrics were actually imported in order to produce high-quality clothes for the foreign market. $40 \%$ of Zhejiang's weaving looms are shuttleless models, compared to $72 \%$ in Shaoxing and $90 \%$ in the most advanced countries. ${ }^{(32)}$ The innovations and brand creation so strongly encouraged by the local authorities represent a high cost and, indeed, a risk of counterfeiting for some small and medium companies, which therefore continue to make do with gambling on prices. In order to overcome these difficulties, the central state and provincial governments are drawing up new policies.

\section{New public policies}

While the central state sets broad economic guidelines, in particular through the Five-Year Plan, provincial and local governments each define their own areas for development following guidelines established in Beijing. In line with the change in tone in national policy, the government in Zhejiang is no longer aiming for growth at all costs, but is taking other dimensions into consideration and is identifying a number of main areas for development, including innovation, environmental protection, relocation, and a social policy favourable to migrant workers.

Moving upmarket and creation are becoming priority policies. The province has set out its stall to "change Zhejiang from a factory for the world to a

30. Duan Shan and Ning Jianrong, "Hou weiji shiqi Zhejiang fangzhiye jishu shengji de lujing xuanze" (The choice by the textile industry in Zhejiang to go upmarket after the financial crisis), China Textile Leader, No. 4, 2012, pp. 20-25.

31. Ibid., p. 21.

32. Zhejiang sheng kexue jishu ting (Science and Technology Department of Zhejiang Province), Zhejiangsheng fangzhi gongye "shiwu" guihua gangyao (10th five-year plan of the Zhejiang textile industry), available at www.zjkjt.gov.cn/news/node11/detail1102/2004/1102_2311.htm (accessed on 12 February 2015). 
centre of creation" (cong Zhejiang zhizao dao Zhejiang chuangzao 从浙江 制造到浙江创造). In order to do this, cities and districts are creating new economic areas that bring together the most dynamic, innovative, and competitive companies. ${ }^{(33)}$ Zhejiang is shifting from industrial clusters based on the concentration of family workshops in rural areas to the promotion of industrial centres. ${ }^{(34)}$ Shaoxing has a network of 36 industrial clusters, including seven in the textile sector, and a particular concentration in two new industrial areas: Binhai and Keqiao (see Table 4). (35)

The new industrial centres are organised around five different missions: research and development, quality control, training, informatisation, and e-commerce. New systems have been introduced to encourage companies to innovate - design facilities and brands have been created, and there have been moves to collaborate with universities, etc. In 2012, Shaoxing welcomed 70 design companies and ten IT companies specialised in textiles and dyeing. ${ }^{(36)}$

In terms of environmental policies, Zhejiang has established environmental standards by introducing quotas. ${ }^{(37)}$ Electricity consumption and the disposal of waste water are controlled and limited. In Shaoxing, the environmental protection policy implemented from the start of the 2000 s became stricter at the start of the 2010s, with regular controls and punitive measures. Companies that fail to observe environmental standards are hit with a special tax; they are forced to stop production for a set period of time or to restructure their operations. ${ }^{(38)}$

\section{Internationalisation and relocation}

The new development policy, "Leave Zhejiang in order to develop it" (tiaochu Zhejiang, fazhan Zhejiang 跳出浙江, 发展浙江) ${ }^{(39)}$ constitutes another important part of provincial strategies to overcome problems relating to a shortage of land and raw materials, and to encourage companies to innovate. This policy of opening up no longer only concerns the expansion of marketing networks that took place in the 1990s, but now also incorporates the relocation of production. Indeed, it can be split into two areas. The first concerns the internationalisation of marketing networks and production. This is the case, for example, of Prato in Italy, where Chinese business people, working closely with Zhejiang Province, have been setting up businesses since the 1990s, making the city into an industrial and commercial cluster in the ready-to-wear sector. An acceleration in the relocation movement can also be seen with the shift of production to low-cost countries. This movement is strongly backed by central and provincial governments. For example, in 2004, the Ministry of Commerce published a guide for textile companies wishing to invest in Latin America (Colombia and Mexico), the Middle East (Israel and Jordan), South Asia (India), and Southeast Asia (Cambodia, Thailand), as well as North and Sub-Saharan Africa.

The second area concerns the relocation of textile companies within China to less developed regions. For example, in response to the national policy to help development in the western regions, Zhejiang is collaborating with the cotton-producing region of Xinjiang with a view to transferring part of its textile production there. Companies from Wenzhou were the first to install their operations in this region at the start of the 2000s, and from the second half of the 2000s, Xinjiang has seen a massive influx of companies from Zhejiang. ${ }^{(40)}$ In 2011, China Textile City in Shaoxing signed an agreement with the region of Aksu (Akesu 阿克苏) to facilitate the relocation there of companies from Shaoxing. An administrative department was created in the municipality to help companies to this end. Relocation is not always a voluntary choice. It can be seen as the only option, in particular for small companies that have limited means when it comes to new technological and environmental standards. ${ }^{(41)}$

In addition to relocation, some large companies are choosing to diversify their activities. For some of the companies visited during our research, entering new sectors of activity is a way to ensure survival. For example, companies 3,8 , and 11 have invested in cement production, mining, department stores, and property (see Table 1). In an uncertain economic climate, companies that have the means to do so are looking to invest elsewhere, in safer and more profitable sectors.

Indeed, the new economic policies, with their strong focus on innovation, the environment, relocation, and internationalisation, are not unique to Zhejiang. They were introduced throughout China in the 2000s. There are obstacles when it comes to their application, and they sometimes meet with incomprehension or even give rise to confusion amongst businessmen and even among the local authorities. When we met the mayor of Shaoxing in 2011, he spoke of the delicate relationship between the provincial government and economic actors:

Zhejiang is currently going through a difficult period: on the one hand, by promoting innovation and the environment, our province is being punished when it comes to competition with other provinces. Zhejiang was the first province to introduce a far-sighted environmental policy. In doing so, we dropped back a few places in the national ranking based on gross national product; on the other hand, companies do not understand the environmental policy. They feel it is full of constraints, and relations between the local government and companies are a little tense. ${ }^{(42)}$

Zhejiang is not an isolated case. Other provinces and regions have come up against the same difficulties. When Zhejiang implemented the "Leave

33. This process is referred to as "Parceled economy," which is defined as the grouping together of companies whose industrial production value is greater than 100 million yuan. See Economic \& Trade Commission of Zhejiang Province, Zhejiang "kuaizhuang jingji" fazhan baogao (Report on the "parceled economy" in Zhejiang), Zhejiang jingji, No. 12, 2006, p. 24.

34. Sheng Shihao and Zheng Yanwei, Jingzheng youshi: Zhejiang chanye jiqi yanbian he fazhan yanjiu (Competitivities: Study on the evolution and development of industry in Zhejiang), Hangzhou, Zhejiang daxue chubanshe, 2009.

35. Lao Jianfang, "Kuaizhuang jingji bixu zou chuangxin tisheng zhilu - Guanyu fazhan tisheng Shaoxing kuaizhuang jingji de sikao" (The parceled economy must move towards innovation - Reflection on the upgrading of the parceled economy in Shaoxing), Zhejiang jingji, No. 16, 2006, pp. 48-49.

36. Zhang Guoyun, "Mianlin gezhong zhiyue, Zhejiang fangzhi ruhe zai tengfei?" (Faced with constraints, how can Zhejiang give its textile industry a boost?), Zhejiang jingmaowang, 6 January 2012, available at www.zjjm.gov.cn/show-6625.html (accessed on 5 April 2015).

37. Sheng Shihao and Zheng Yanwei, Jingzheng youshi: Zhejiang chanye jiqi yanbian he fazhan yanjiu (Competitivities: Study on the evolution and development of industry in Zhejiang), op. cit.

38. Zhejiangsheng fangzhi gongye "shierwu" fazhan guihua (12th five-year plan of the Zhejiang textile industry), op. cit., pp. 7-8.

39. Zhejiangsheng zhiyuan Xinjiang zhihuibu (Zhejiang assistance service to Xinjiang), "Zhejiang: tuidong chanye zhuanyi, shixian huli shuangying, zhutui Xinjiang fangzhi gongye, shixian kuayue fazhan" (Promoting the transfer of production and helping the textile industry of Xinjiang to grow), 18 July 2011, available at www.miit.gov.cn/n11293472/n11293877/n13944206/n13944275/ 13945197.html (accessed on 2 February 2015).

40. In July 2010 , the Ministry of Industry and Information Technology stated that spinning and weaving activities needed to be transferred to the centre and West of the country in order to allow the Eastern region to upgrade to more high-end activities. See the Consumer Industries Bureau, "Guanyu tuijin fangzhi chanye zhuanyi de zhidao yijian" (Report on promoting the transfer of the textile industry), 2 July 2010, available at www.miit.gov.cn/n11293472/n11293832/ n12843926/n13917057/14016570.html (accessed on 10 February 2015).

41. Kang Jian, Lin Changqing, et al., "Hangzhou qiye waiqian yuanyin fenxi ji huanjing youhua yanjiu" (Analysis of the relocation of companies from Hangzhou and study on optimisation of the environment), Hangzhoushi shehui kexue lianhehui, 22 January 2015, available at www.hzsk.com/ portal/n2994c97.shtml (accessed on 1 June 2015).

42. Interview conducted in May 2011 with M. Gao, mayor of Shaoxing. 
Zhejiang in order to develop it" policy, Guangdong Province opted for an intraprovincial relocation policy (tenglong huanniao 腾笼换鸟, referred to as "chasing the old bird from its cage"). This involved moving manufacturing companies operating at a low technological level into new industrial areas to the north, east, and west of Guangdong in order to attract the tertiary sector and high tech companies (tuier jinsan 退二进三, "pushing back industry in favour of the tertiary sector"). This policy, which came into force in 2008 , has not been without consequences on local economic life. Some villages and townships have seen the departure of industrial companies that were pillars of the local economy but have been unable to attract new innovative companies in their stead. This strategy has even acted as a brake on local development and has not been accepted without its fair share of challenges. In Dongguan, for example, the local authorities opted for an alternative measure, encouraging companies to embrace innovation without relocating (jiudi shengji 就地升级, "moving upmarket on the spot"). Therefore, after the aborted experiment in the township of Humen in the IT and electronics sector, it was able to focus once again on a traditional, profitable activity: ready-to-wear clothing. This ability to adjust and show flexibility enabled the local authorities in Dongguan to make Humen into one of the largest ready-to-wear clusters. ${ }^{(43)}$

\section{An innovative social policy for migrants}

In the textile companies visited, between $50 \%$ and $80 \%$ of the workers were migrants, mainly from neighbouring provinces. The 2000 s also opened with an innovative social policy aimed at migrants and targeted towards helping them integrate economically and socially. The central government encouraged local authorities to give migrants the same social rights as their own residents in terms of social protection, access to jobs and housing, and education for their children. The new social policy forced companies to increase workers' wages and provide better working and living conditions in order to further help the integration of migrants.

This social policy in favour of migrants sometimes meets with reluctance, and indeed resistance, from the local authorities. They essentially point to the problems experienced by host towns in terms of infrastructure, public services, and budget constraints when it comes to receiving an ever-increasing migrant population. Indeed, host towns set aside a considerable proportion of their budget to integrating migrants and their families, to the detriment of local residents, while the funding granted to migrants by the state is included in the budget of their provinces of origin. Zhejiang is one of the few provinces to educate the children of migrants in its public schools and to provide social housing for migrants. This social policy in favour of migrants has resulted in a major increase in the migrant population. In 2010, the number of residents originally from other provinces was $11,820,000$ whereas ten years earlier, in 2000, they numbered 3,690,000. In 2012, migrants represented $22 \%$ of the population of Zhejiang. ${ }^{(44)}$

\section{Conclusion}

Shaoxing has gone through several stages over the course of its development, and has experienced significant transformations on the road to becoming, at present, the city offering the highest concentration of textile companies in various sectors of production, including dyeing and equipment, fabrics and embroidery, and socks and ties. It is one of the largest textile manufacturing centres in the world. However, Shaoxing is not just a factory for the world. With the emergence of research and innovation centres, Shaoxing is showing its ambition to become a centre of creation and innovation. The economic success of the city is the result of its strategy to encourage its companies to embrace globalisation. The presence of highly organised marketing facilities alongside production facilities constitutes one of the main distinguishing features of the industrial districts in Shaoxing and elsewhere in China. This considerable commercial dimension gives the local economy a particular configuration. Encouraged by the authorities, from the middle of the 1990s, companies turned towards the international markets, favouring exports. However, the deterioration of the economic situation and the change in foreign trade policy from the middle of the last decade forced many of them to turn increasingly back to the domestic market. The new policy of relocating and internationalising production has prompted companies to once again look further than China's borders and conquer the world market. The example of Shaoxing shows that companies can build momentum in this setup that combines production and marketing, and that they also need to be able keep their relationship with the markets and political power continually up-to-date.

The development trajectory of the textile sector in Shaoxing provides an opportunity to rethink the developmental state concept. From the middle of the 1980s, and in the 1990s in particular, new ways of organising production emerged in the form of industrial districts. The expansion of these districts provided the basis for Shaoxing's development. The textile industry in Shaoxing is characterised by an endogenous development model: the setting up of small-scale industrial activities in rural areas, the spontaneous development of production workshops in an urbanising countryside, and considerable specialisation in terms of production. These family or collective production workshops transformed in the 1990s into industrial districts, at the same time adopting modern legal forms such as collective shareholding companies or limited liability companies. Some companies have now been incorporated into industrial groups listed on the stock market.

This new configuration of production and institutional innovation calls for new forms of intervention from a state whose role is changing with the decentralisation of economic and administrative power. This change is modifying relationships between companies and the local state. The latter now needs to maintain many complex relationships with economic actors, playing the role of decision maker, collaborator, and regulator. In its decisionmaking role, the local state has kept and continues to keep a grip on the local economy. Although it is no longer the main actor, it remains at the forefront. The local state is also a collaborator, participating in the life of the company as a shareholder. The series of economic reforms in the 2000s put in place a new mode of governance in keeping with the new model of public intervention as advocated by the central government - a "serviceoriented government" (fuwuxing zhengfu 服务型政府). The local government also plays a regulatory role in that it guides development in one direction or another by means of a series of mechanisms. Local initiatives concerning protection of the environment and social policy suggest that

43. Xu Jianniu and Li Huai, "From Upgrade Locally to Transfer to Other Places -Evolution of the Pearl River Delta Cluster Policy," International workshop, Industrial clusters and centres of competitivity - Transformations in local governance methods and the evolution of public intervention systems in China, 22-23 March 2012, ENS-Lyon; Qiu Haixiong, Yu Yonghui, and Qiu Qing, "Zhusanjiao chuantong chanye chulu hezai - laizi Guangdong Dongguan Humen de diaoyan baogao" (What are the prospects for the traditional industry of the Pearl River Delta - a study of Humen in Dongguan in Guangdong Province), Xueshu yanjiu, No. 10, 2008, pp. 45-51.

44. Zhang Zhaowei, "Zhejiangsheng wailai renkou fenxi" (Analysis of the migrant population of Zhejiang), Tongji kexue yu shijian, No. 2, 2012, pp. 16-18. 
public action does not merely support growth; it can also act as a constraint. Although Zhejiang was industrialised by a developmentalist alliance between the local state and the owners of capital, this relationship has evolved. Therefore, it is not only companies that have changed; the public power-holders have also adopted new practices.

Finally, over the past ten years, Chinese industrial growth has been built largely on the policy of industrial clusters, the aim of which is to drive China towards innovation and globalisation. The success of these clusters is largely due to the intervention of public power at the national, provincial, and local levels. Central and local power-holders have attempted to develop their mode of governance from a decision-making role to one in which they pro- vide companies with support and assistance. However, the state continues to be a major presence in economic management. Interventions by the political leadership in the development of industrial clusters are a continual presence in a context of international competition.

I Translated by Will Thornely.

I Shi Lu is an associate professor in Chinese studies at Jean Moulin Lyon 3 University and a researcher at the Institut d'Asie Orientale, UMR 5062, ENS-Lyon.

Institut d'Asie Orientale, ENS-Lyon, 15 Parvis René Descartes, 69007 Lyon, France (lu.shi@ens-lyon.fr). 